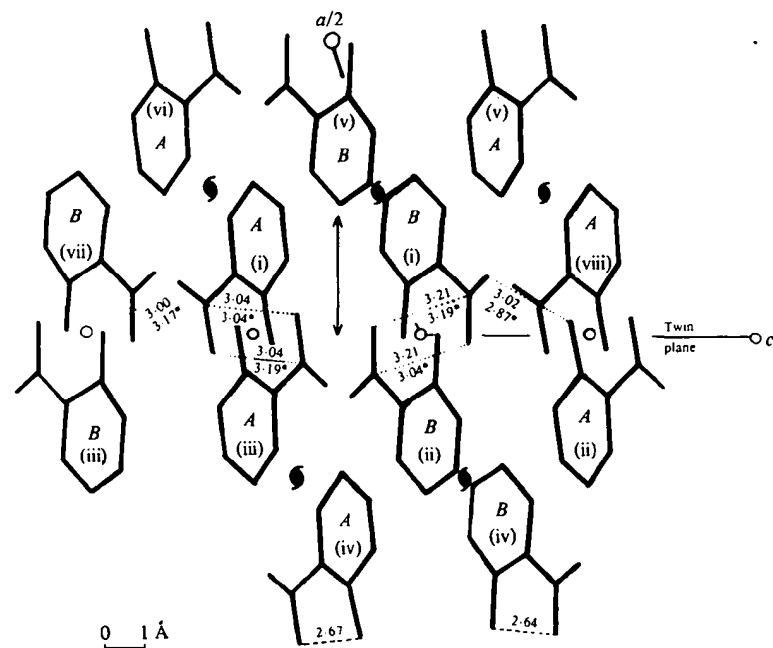

Fig. 2. Structure projected on (010). Symmetry code: (i) $x, y, z$; (ii) $\bar{x}, \bar{y}, \bar{z}$; (iii) $\bar{x}, \bar{y},-1-z$; (iv) $x-\frac{1}{2}, \frac{1}{2}-y, z$; (v) $\frac{1}{2}-x, \frac{1}{2}+y, \bar{z}$; (vi) $\frac{1}{2}-x, \frac{1}{2}+y,-1-z$; (vii) $x, y, z-1$; (viii) $x, y, z+1$. An asterisk indicates an intermolecular contact after rotation about the pseudo twofold axis.

unaffected to a good approximation. Some of the intermolecular contacts near the twin plane before and after rotation are shown in the figure. The similarity of the contacts probably explains why the crystal is twinned so easily on the (100) plane.

It is reported by Herbstein (1965) that the reflexions on the $h k 0$ Weissenberg photographs of $\gamma$-o-nitroaniline crystals are sharp, but those on the $h k 1$ photographs are joined by weak diffuse streaks running parallel to $a^{*}$. It seems that the individual untwinned regions in the crystal are in general thick enough to give sharp reflexions in the $\mathrm{X}$-ray photographs. However, there are also regions in the crystal where twinning occurs after only a few molecular layers; these regions lead to continuous diffuse streaks. The absence of diffuse streaks in the $h k 0$ Weissenberg photographs can be explained as follows.

The parameters of equivalent positions in the (001) projection in space group $P 2_{1} / a$ are: $x, y ; \frac{1}{2}+x, \frac{1}{2}-y$; $\frac{1}{2}-x, \frac{1}{2}+y ; \bar{x}, \bar{y}$. On applying the twin operation of rotation about the pseudo twofold axis, the parameters become: $x, \frac{1}{2}-y ; \frac{1}{2}+x, y ; \frac{1}{2}-x, \bar{y} ; \bar{x}, \frac{1}{2}+y$. It can be seen that the twin operation alters the $x$ parameters of the first set of points by half; thus corresponding to the point $x, y$ in the first set, there is a point $\frac{1}{2}+x, y$ in the second set and so on. This implies that the structure factors $F(h k 0)$ with $h$ even will remain unaffected by twinning and will continue to be sharp. In principle, $F(h k 0)$ with $h$ odd should show diffuse streaks; however, these diffuse streaks are imperceptible because $F(h k 0)$ with $h$ odd are very weak due to the near cancellation of scattering from molecules $A$ and $B$. This is apparent in the structure factor tables.*

\footnotetext{
* Lists of structure factors and anisotropic thermal parameters have been deposited with the British Library Lending Division as Supplementary Publication No. SUP 33492 (8 pp.). Copies may be obtained through The Executive Secretary, International Union of Crystallography, 5 Abbey Square, Chester CH1 2HU, England.
}

\section{References}

Gantzel, P. K., Sparks, R. A. \& Trueblood, K. N. (1961). LALS. Full-Matrix Least-Squares Refinement of Positional and Thermal Parameters and Scale Factors.

Herbstein, F. H. (1965). Acta Cryst. 19, 590-595.

LONG, R. E. (1965). Dissertation, parts II and III, Univ. of California, Los Angeles.

Acta Cryst. (1978). B34, 2509-2514

\title{
The Crystal Structure of 5-Benzoyloxyoctaethylporphyrin
}

\author{
By S. NEIDLE \\ Department of Biophysics, King's College, University of London, 26-29 Drury Lane, London WC2B 5RL, \\ England
}

AND M. B. HURSTHOUSE

Department of Chemistry, Queen Mary College, Mile End Road, London E1 4NS, England

(Received 16 January 1978; accepted 23 March 1978)

\begin{abstract}
5-Benzoyloxyoctaethylporphyrin, $\mathrm{C}_{43} \mathrm{H}_{50} \mathrm{~N}_{4} \mathrm{O}_{2}$, monoclinic, $P 2_{1} / c, a=15 \cdot 105(1), b=20 \cdot 729(2), c=$ 12.721 (1) $\AA, \beta=112.05(2)^{\circ}, D_{m}=1.18, D_{c}=1.177 \mathrm{~g} \mathrm{~cm}^{-3}$ for $Z=4$. The structure was solved by direct methods, and refined to $R=0.0474, R_{w}=0.0510$ for 4076 reflections measured on an automatic diffractometer. The central porphyrin system is distinctly non-planar, and adopts a shallow saucer shape. A 'halfhydrogen' atom has been located attached to each central nitrogen atom; however, it is not clear whether these are truly representative of $\mathrm{N}-\mathrm{H}$ tautomerism, or are crystallographic artifacts.
\end{abstract}




\section{Introduction}

Substitution at the meso position has been considered to be an important step in the degradation of the closedring porphyrins in hæmoglobin and other hæmoproteins. This degradation leads to the open-chain tetrapyrrolic bile pigments (Bonnett, 1972).

The structure of the title compound (BOEP) has been investigated in order to ascertain the effects of meso-substitution on the porphyrin skeleton. In this paper we present the details of the fully refined structure; preliminary results have been previously discussed elsewhere (Hursthouse \& Neidle, 1972).

\section{Experimental}

Crystals of BOEP, as supplied by Professor R. Bonnett, were deep-red lustrous crystals. Preliminary Weissenberg and oscillation photographs showed the crystals to be monoclinic. Systematic absences $h 0 l: l=$ $2 n+1$ and $0 k 0: k=2 n+1$ showed the space group to be $P 2_{1} / c$. Cell dimensions were obtained by leastsquares refinement of $2 \theta$ values for 18 high-order reflections.

\section{Crystal data}

$\mathrm{C}_{43} \mathrm{H}_{50} \mathrm{~N}_{4} \mathrm{O}_{2}, \mathrm{FW}$ 654.4. Monoclinic prisms, elongated along a. $a=15 \cdot 105$ (1), $b=20 \cdot 729$ (2), $c=12.721$ (1) $\AA, \beta=112.05(2)^{\circ}, V=3691.75 \AA^{3}, D_{m}=1.18(2) \mathrm{g}$ $\mathrm{cm}^{-3}, D_{c}=1.177 \mathrm{~g} \mathrm{~cm}^{-3}$ for $Z=4 . F(000)=1408$, $\mu=4.9 \mathrm{~cm}^{-1}$ for $\mathrm{Cu} K \alpha$ radiation $(\lambda=1.54178 \AA)$. Space group $P 2_{1} / c$ (No. 14).

Intensities were collected on a Siemens AED diffractometer using a coupled $\omega: 2 \theta$ scan and a fivevalue measuring technique (Allen, Rogers \& Troughton, 1971), for a crystal of approximate dimensions $0.3 \times 0.2 \times 0.1 \mathrm{~mm}$, to a limit of $120^{\circ}$ in $2 \theta$ (corresponding to a resolution limit of $0.89 \AA$ ), for $\mathrm{Ni}$-filtered $\mathrm{Cu} K \alpha$ radiation. A total of 5410 reflections were measured; of these, 4076 were considered to be significantly above background $[I>2 \cdot 5 \sigma(I)]$.

The structure was solved by direct methods (Long, 1965), and refined by full-matrix least-squares methods. All $\mathrm{H}$ atoms were located in a difference Fourier synthesis, with heights between 0.4 and 0.8 e $\AA^{-3}$. Among the peaks located there were four, one attached to each of the four ring $\mathrm{N}$ atoms. Refinement converged to $R=0.0474$ and $R_{w}=0.0510$ with parameter shifts less than 0.15 of their corresponding standard deviations. All positional parameters were refined, together with isotropic thermal parameters for the $\mathrm{H}$ atoms and anisotropic ones for the non-hydrogen atoms. Weights used were derived from counting
Table 1. Final positional parameters for the nonhydrogen atoms $\left(\times 10^{4}\right)$

Estimated standard deviations are in parentheses.

$\begin{array}{lccc} & x & y & z \\ \mathrm{C}(1) & 17490(1) & 4898(1) & 3309(2) \\ \mathrm{C}(2) & 18459(1) & 4658(1) & 3675(2) \\ \mathrm{C}(3) & 18501(1) & 4141(1) & 4370(2) \\ \mathrm{C}(4) & 17586(1) & 4074(1) & 4458(2) \\ \mathrm{C}(5) & 17376(2) & 3635(1) & 5159(2) \\ \mathrm{C}(6) & 16528(2) & 3558(1) & 5328(2) \\ \mathrm{C}(7) & 16369(2) & 3101(1) & 6115(2) \\ \mathrm{C}(8) & 15455(2) & 3175(1) & 6030(2) \\ \mathrm{C}(9) & 15038(2) & 3685(1) & 5205(2) \\ \mathrm{C}(10) & 14115(2) & 3919(1) & 4871(2) \\ \mathrm{C}(11) & 13705(1) & 4397(1) & 4062(2) \\ \mathrm{C}(12) & 12726(1) & 4618(1) & 3686(2) \\ \mathrm{C}(13) & 12631(1) & 5082(1) & 2889(2) \\ \mathrm{C}(14) & 13543(1) & 5148(1) & 2773(2) \\ \mathrm{C}(15) & 13745(2) & 5569(1) & 2052(2) \\ \mathrm{C}(16) & 14598(1) & 5655(1) & 1893(2) \\ \mathrm{C}(17) & 14729(1) & 6082(1) & 1056(2) \\ \mathrm{C}(18) & 15657(1) & 6041(1) & 1167(2) \\ \mathrm{C}(19) & 16110(1) & 5587(1) & 2094(2) \\ \mathrm{C}(20) & 17070(1) & 5407(1) & 2568(2) \\ \mathrm{N}(21) & 16976(1) & 4533(1) & 3785(1) \\ \mathrm{N}(22) & 15711(1) & 3899(1) & 4800(1) \\ \mathrm{N}(23) & 14182(1) & 4722(1) & 3496(1) \\ \mathrm{N}(24) & 15444(1) & 5354(1) & 2482(1) \\ \mathrm{O}(25) & 17711(1) & 5782(0) & 2246(1) \\ \mathrm{C}(26) & 17936(2) & 6380(1) & 2755(2) \\ \mathrm{O}(27) & 17610(1) & 6572(1) & 3428(2) \\ \mathrm{C}(28) & 18608(2) & 6738(1) & 2371(2) \\ \mathrm{C}(29) & 19113(2) & 6458(1) & 1778(2) \\ \mathrm{C}(30) & 19761(2) & 6810(2) & 1512(3) \\ \mathrm{C}(31) & 19889(2) & 7459(2) & 1786(3) \\ \mathrm{C}(32) & 19388(3) & 7744(1) & 2360(3) \\ \mathrm{C}(33) & 18738(2) & 7383(1) & 2645(2) \\ \mathrm{C}(34) & 19249(1) & 4872(1) & 3319(2) \\ \mathrm{C}(35) & 19121(2) & 4651(1) & 2128(2) \\ \mathrm{C}(36) & 19327(2) & 3687(1) & 4899(2) \\ \mathrm{C}(37) & 19227(2) & 3081(1) & 4196(3) \\ \mathrm{C}(38) & 17140(2) & 2661(1) & 6899(2) \\ \mathrm{C}(39) & 17297(3) & 2065(2) & 6347(3) \\ \mathrm{C}(40) & 14913(2) & 2816(1) & 6622(2) \\ \mathrm{C}(41) & 14280(3) & 2284(1) & 5912(3) \\ \mathrm{C}(42) & 11987(2) & 4365(1) & 4096(2) \\ \mathrm{C}(43) & 11535(3) & 3734(2) & 3532(4) \\ \mathrm{C}(44) & 11748(2) & 5452(1) & 2212(2) \\ \mathrm{C}(45) & 11255(3) & 5186(3) & 1025(3) \\ \mathrm{C}(46) & 13936(2) & 6469(1) & 208(2) \\ \mathrm{C}(47) & 13380(3) & 6083(2) & -836(3) \\ \mathrm{C}(48) & 16073(2) & 6331(1) & 372(2) \\ \mathrm{C}(49) & 16273(3) & 5827(2) & -384(3)\end{array}$

statistics, and were of the form $w=1 / \sigma^{2}(F)$. As a final check on the authenticity of the four inner-ring hydrogens (each of which was assigned a halfoccupancy during the refinement), a difference Fourier synthesis was computed with contributions from all $\mathbf{H}$ atoms other than these four. This map was essentially featureless except for the re-appearance of the four 'half-hydrogens' in the expected positions, with the heights given in Table 6 . There were no other features on the map with heights greater than $0.14 \mathrm{e} \AA^{-3}$. 
Table 2. Final positional $\left(\times 10^{3}\right)$ and thermal $(U)$ $\left(\AA^{2} \times 10^{3}\right)$ parameters for the hydrogen atoms

The atom numbering denotes the atom to which each hydrogen is bonded. Estimated standard deviations are in parentheses. The average $X-\mathrm{H}$ distance is 1.02 (14) $\AA$.

\begin{tabular}{|c|c|c|c|c|}
\hline & $x$ & $y$ & $z$ & $U$ \\
\hline $\mathrm{H}(5)$ & 797 (1) & $330(1)$ & $564(1)$ & $49(6)$ \\
\hline$H(10)$ & $366(1)$ & $368(1)$ & $522(2)$ & $60(7)$ \\
\hline$H(15)$ & 315 (1) & 587 (1) & $151(2)$ & $52(7)$ \\
\hline$N(21)$ & $697(3)$ & 453 (2) & $378(3)$ & 48 (13) \\
\hline$N(22)$ & $571(3)$ & $389(2)$ & $480(4)$ & $54(14)$ \\
\hline$N(23)$ & $418(2)$ & 472 (1) & 349 (3) & 49 (11) \\
\hline$N(24)$ & $544(3)$ & $535(2)$ & $248(3)$ & $48(13)$ \\
\hline$H(29)$ & 893 (2) & 605 (1) & $147(2)$ & $97(10)$ \\
\hline $\mathrm{H}(30)$ & $1007(2)$ & 661 (1) & $106(2)$ & $90(10)$ \\
\hline $\mathrm{H}(31)$ & $1039(2)$ & $772(1)$ & $166(3)$ & $146(14)$ \\
\hline$H(32)$ & $953(2)$ & $818(1)$ & $262(3)$ & $144(14)$ \\
\hline$H(33)$ & $842(2)$ & 755 (1) & 299 (2) & $88(9)$ \\
\hline $\mathrm{H}(341)$ & 991 (1) & $468(1)$ & 387 (2) & $67(8)$ \\
\hline$H(342)$ & 930 (1) & 532 (1) & $333(2)$ & $62(7)$ \\
\hline $\mathrm{H}(351)$ & $906(2)$ & $417(1)$ & $208(2)$ & 99 (10) \\
\hline$H(352)$ & 850 (1) & 484 (1) & $153(2)$ & $79(8)$ \\
\hline$H(353)$ & $974(2)$ & 483 (1) & $198(2)$ & $107(11)$ \\
\hline$H(361)$ & 933 (1) & 354 (1) & 567 (2) & $69(8)$ \\
\hline $\mathrm{H}(362)$ & 992 (1) & 389 (1) & $497(2)$ & $79(8)$ \\
\hline $\mathrm{H}(371)$ & $855(2)$ & $290(1)$ & 399 (2) & $120(11)$ \\
\hline$H(372)$ & $977(2)$ & 283 (1) & 449 (3) & 124 (13) \\
\hline $\mathrm{H}(373)$ & $913(2)$ & 319 (1) & $337(2)$ & $117(10)$ \\
\hline$H(381)$ & $712(2)$ & $261(1)$ & $766(2)$ & $79(9)$ \\
\hline $\mathrm{H}(382)$ & $785(2)$ & 285 (1) & $741(2)$ & $106(11)$ \\
\hline H(391) & $664(2)$ & $184(1)$ & 599 (2) & $115(10)$ \\
\hline$H(392)$ & $758(2)$ & 219 (1) & $563(3)$ & $166(16)$ \\
\hline$H(393)$ & $791(3)$ & $180(2)$ & $708(3)$ & $178(17)$ \\
\hline $\mathrm{H}(401)$ & 534 (1) & $263(1)$ & 724 (2) & $61(7)$ \\
\hline$H(402)$ & $440(2)$ & $313(1)$ & $680(2)$ & 95 (10) \\
\hline $\mathrm{H}(411)$ & $467(2)$ & 194 (1) & $568(2)$ & $147(12)$ \\
\hline $\mathrm{H}(412)$ & $388(2)$ & 208 (1) & $630(3)$ & $122(13)$ \\
\hline$H(413)$ & $372(2)$ & 243 (1) & $515(2)$ & $116(10)$ \\
\hline H(421) & $228(1)$ & $428(1)$ & $488(2)$ & $76(8)$ \\
\hline $\mathrm{H}(422)$ & $140(1)$ & 471 (1) & 389 (2) & $76(8)$ \\
\hline$H(431)$ & $99(2)$ & $356(1)$ & $386(3)$ & $142(15)$ \\
\hline $\mathrm{H}(432)$ & $205(2)$ & 332 (1) & $376(3)$ & $128(14)$ \\
\hline H(433) & $115(2)$ & $380(2)$ & $269(3)$ & $131(17)$ \\
\hline $\mathrm{H}(441)$ & $124(1)$ & 545 (1) & $262(2)$ & $64(8)$ \\
\hline$H(442)$ & $187(2)$ & $590(1)$ & $215(2)$ & $82(10)$ \\
\hline $\mathrm{H}(451)$ & $106(2)$ & 472 (1) & $103(3)$ & $115(15)$ \\
\hline$H(452)$ & $170(3)$ & $515(2)$ & $60(3)$ & $141(17)$ \\
\hline$H(453)$ & $65(2)$ & $540(1)$ & $56(3)$ & $117(14)$ \\
\hline$H(461)$ & $417(2)$ & $685(1)$ & $0(2)$ & $80(10)$ \\
\hline$H(462)$ & 343 (1) & 673 (1) & $53(2)$ & $68(8)$ \\
\hline $\mathbf{H}(471)$ & $280(2)$ & $636(1)$ & $-137(3)$ & $126(13)$ \\
\hline H(472) & $303(3)$ & 569 (2) & $-54(3)$ & $153(17)$ \\
\hline$H(473)$ & $393(3)$ & $602(2)$ & $-112(4)$ & $203(26)$ \\
\hline H(481) & 667 (1) & 656 (1) & $80(2)$ & $53(7)$ \\
\hline $\mathrm{H}(482)$ & $557(1)$ & $666(1)$ & $-13(2)$ & $62(8)$ \\
\hline$H(491)$ & $652(2)$ & 605 (1) & $-94(3)$ & $105(12)$ \\
\hline H(492) & $567(2)$ & $561(1)$ & $-78(3)$ & $110(14)$ \\
\hline H(493) & $679(2)$ & $545(2)$ & $7(3)$ & $133(15)$ \\
\hline
\end{tabular}

Final atomic coordinates are given in Tables 1 and 2 *

* Tables of structure factors, and of anisotropic temperature factors, have been deposited with the British Library Lending Division as Supplementary Publication No. SUP 33473 (15 pp.). Copies may be obtained through The Executive Secretary, International Union of Crystallography, 5 Abbey Square, Chester $\mathrm{CH} 1$ 2HU, England.
Table 3. Non-hydrogen bond lengths ( $\AA$ )

Estimated standard deviations are in parentheses.

$\begin{array}{llll}\mathrm{C}(2)-\mathrm{C}(1) & 1.447(4) & \mathrm{C}(17)-\mathrm{C}(16) & 1.454(4) \\ \mathrm{C}(20)-\mathrm{C}(1) & 1.398(3) & \mathrm{N}(24)-\mathrm{C}(16) & 1.366(3) \\ \mathrm{N}(21)-\mathrm{C}(1) & 1.378(4) & \mathrm{C}(18)-\mathrm{C}(17) & 1.358(4) \\ \mathrm{C}(3)-\mathrm{C}(2) & 1.375(4) & \mathrm{C}(46)-\mathrm{C}(17) & 1.508(4) \\ \mathrm{C}(34)-\mathrm{C}(2) & 1.495(4) & \mathrm{C}(19)-\mathrm{C}(18) & 1.463(3) \\ \mathrm{C}(4)-\mathrm{C}(3) & 1.434(4) & \mathrm{C}(48)-\mathrm{C}(18) & 1.501(5) \\ \mathrm{C}(36)-\mathrm{C}(3) & 1.505(4) & \mathrm{C}(20)-\mathrm{C}(19) & 1.396(3) \\ \mathrm{C}(5)-\mathrm{C}(4) & 1.392(4) & \mathrm{N}(24)-\mathrm{C}(19) & 1.365(4) \\ \mathrm{N}(21)-\mathrm{C}(4) & 1.376(3) & \mathrm{O}(25)-\mathrm{C}(20) & 1.418(4) \\ \mathrm{C}(6)-\mathrm{C}(5) & 1.386(5) & \mathrm{C}(26)-\mathrm{O}(25) & 1.380(3) \\ \mathrm{C}(7)-\mathrm{C}(6) & 1.461(4) & \mathrm{O}(27)-\mathrm{C}(26) & 1.204(5) \\ \mathrm{N}(22)-\mathrm{C}(6) & 1.362(3) & \mathrm{C}(28)-\mathrm{C}(26) & 1.480(5) \\ \mathrm{C}(8)-\mathrm{C}(7) & 1.353(5) & \mathrm{C}(29)-\mathrm{C}(28) & 1.386(5) \\ \mathrm{C}(38)-\mathrm{C}(7) & 1.521(4) & \mathrm{C}(33)-\mathrm{C}(28) & 1.377(4) \\ \mathrm{C}(9)-\mathrm{C}(8) & 1.457(4) & \mathrm{C}(30)-\mathrm{C}(29) & 1.362(6) \\ \mathrm{C}(40)-\mathrm{C}(8) & 1.501(5) & \mathrm{C}(31)-\mathrm{C}(30) & 1.384(6) \\ \mathrm{C}(10)-\mathrm{C}(9) & 1.384(4) & \mathrm{C}(32)-\mathrm{C}(31) & 1.368(7) \\ \mathrm{N}(22)-\mathrm{C}(9) & 1.373(4) & \mathrm{C}(33)-\mathrm{C}(32) & 1.387(6) \\ \mathrm{C}(11)-\mathrm{C}(10) & 1.395(4) & \mathrm{C}(35)-\mathrm{C}(34) & 1.523(5) \\ \mathrm{C}(12)-\mathrm{C}(11) & 1.448(4) & \mathrm{C}(37)-\mathrm{C}(36) & 1.517(5) \\ \mathrm{N}(23)-\mathrm{C}(11) & 1.371(4) & \mathrm{C}(39)-\mathrm{C}(38) & 1.483(6) \\ \mathrm{C}(13)-\mathrm{C}(12) & 1.365(4) & \mathrm{C}(41)-\mathrm{C}(40) & 1.516(5) \\ \mathrm{C}(42)-\mathrm{C}(12) & 1.495(5) & \mathrm{C}(43)-\mathrm{C}(42) & 1.525(5) \\ \mathrm{C}(14)-\mathrm{C}(13) & 1.445(4) & \mathrm{C}(45)-\mathrm{C}(44) & 1.514(6) \\ \mathrm{C}(44)-\mathrm{C}(13) & 1.498(4) & \mathrm{C}(47)-\mathrm{C}(46) & 1.508(5) \\ \mathrm{C}(15)-\mathrm{C}(14) & 1.380(4) & \mathrm{C}(49)-\mathrm{C}(48) & 1.527(6) \\ \mathrm{N}(23)-\mathrm{C}(14) & 1.376(3) & & \end{array}$

$\mathrm{N}(23)-\mathrm{C}(14) \quad 1.376(3)$

$\mathrm{C}(16)-\mathrm{C}(15) \quad 1.388(5)$

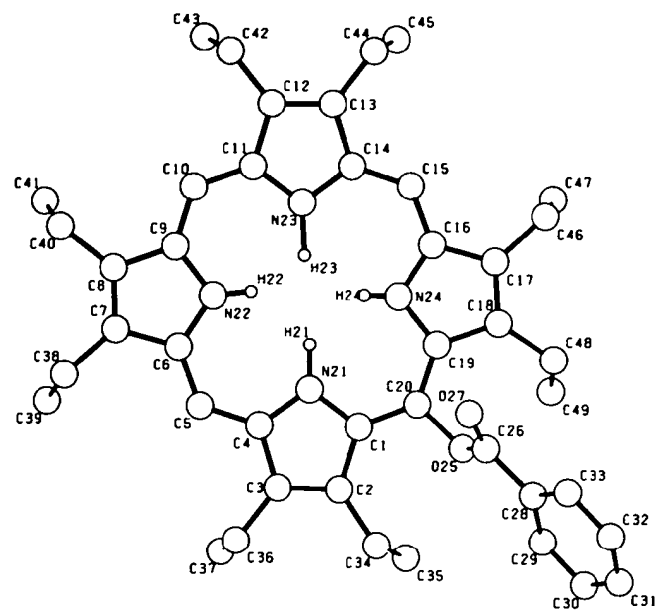

Fig. 1. A view of the molecule, projected onto the plane of the four central nitrogen atoms.

\section{Discussion}

Tables 3 and 4 detail the bond lengths and angles involving non-hydrogen atoms. Fig. 1 shows a projection of the molecule, together with the numbering scheme used. The four pyrrole rings have very similar geometries; however, subtle differences do exist between them, with rings $A$ and $C$ on the one hand, and $B$ 
Table 4. Valence angles $\left({ }^{\circ}\right)$

\begin{tabular}{|c|c|}
\hline (20) $-C(1)-C(2)$ & 120 \\
\hline$N(21)-C(1)-C(2)$ & $109 \cdot 8(2)$ \\
\hline$N(21)-C(1)-C(20)$ & $121 \cdot 5(2)$ \\
\hline$C(3)-C(2)-C(1)$ & $105 \cdot 8(3)$ \\
\hline$C(34)-C(2)-C(1)$ & $128 \cdot 8(2)$ \\
\hline$C(34)-C(2)-C(3)$ & $125 \cdot 2(2)$ \\
\hline$C(4)-C(3)-C(2)$ & $108 \cdot 2(2)$ \\
\hline$C(36)-C(3)-C(2)$ & $127 \cdot 2$ \\
\hline$C(36)-C(3)-C(4)$ & \\
\hline$C(5)-C(4)-C$ & $9(2)$ \\
\hline$N(21)-C(4)-C(3)$ & $\cdot 9(2)$ \\
\hline$N(21)-C(4)-C(5)$ & $126 \cdot 1(3)$ \\
\hline$C(6)-C(5)-C(4)$ & $128.4(2)$ \\
\hline$C(7)-C(6)-C(5)$ & $125 \cdot 5(2)$ \\
\hline$N(22)-C(6)-C(5)$ & $125 \cdot 7(3)$ \\
\hline$N(22)-C(6)-C(7)$ & $108 \cdot 8(3)$ \\
\hline$C(8)-C(7)-C(6)$ & $107 \cdot 4(2)$ \\
\hline$C(38)-C(7)-C(6)$ & (3) \\
\hline$-C(7)-C(8)$ & $128 \cdot 8(3)$ \\
\hline$C(9)-C(8)-C(7)$ & $106 \cdot 9(3)$ \\
\hline$C(40)-C(8)-C(7)$ & $129 \cdot 5(3)$ \\
\hline$C(40)-C(8)-C(9)$ & $123 \cdot 6(3)$ \\
\hline$C(10)-C(9)-C(8)$ & $126 \cdot 0(3)$ \\
\hline$N(22)-C(9)-C(8)$ & $108.9(2)$ \\
\hline$N(22)-C(9)-C(10)$ & $125 \cdot 1(2)$ \\
\hline$C(11)-C(10)-C(9)$ & $126 \cdot 3(3)$ \\
\hline$C(12)-C(11)-C(10)$ & $125 \cdot 7(3)$ \\
\hline$N(23)-$ & $124 \cdot 2(3)$ \\
\hline$N(23)$ & $110 \cdot 1(2)$ \\
\hline$C(13)-C(12)-C(11)$ & $106 \cdot 1(3)$ \\
\hline$C(42)-C(12)-C(11)$ & $125 \cdot 3(2)$ \\
\hline $\mathrm{C}(42)-\mathrm{C}(12)-\mathrm{C}(13)$ & $128 \cdot 5(2)$ \\
\hline$C(14)-C(13)-C(12)$ & $107 \cdot 7(2)$ \\
\hline$C(44)-C(13)-C(12)$ & $127 \cdot 5(3)$ \\
\hline$C(44)-C(13)-C(14)$ & $124 \cdot 7(3)$ \\
\hline$C(15)-C(14)-C(13)$ & $125 \cdot 8(2)$ \\
\hline$N(23)-C(14)-C(13)$ & $109 \cdot 1(3)$ \\
\hline N( & $125 \cdot 1($ \\
\hline
\end{tabular}

$\mathrm{C}(16)-\mathrm{C}(15)-\mathrm{C}(14) 128 \cdot 8$ (2) $\mathrm{C}(17)-\mathrm{C}(16)-\mathrm{C}(15) \quad 125.0$ (2) $\mathrm{N}(24)-\mathrm{C}(16)-\mathrm{C}(15) \quad 126 \cdot 1$ (3) $\mathrm{N}(24)-\mathrm{C}(16)-\mathrm{C}(17) 108.8$ (3) $\mathrm{C}(18)-\mathrm{C}(17)-\mathrm{C}(16) \quad 107.8(2)$ C(46)-C(17)-C(16) 123.9 (3) C(46)-C(17)-C(18) $128 \cdot 3$ (3) C(19)-C(18)-C(17) 106.0 (3) $\mathrm{C}(48)-\mathrm{C}(18)-\mathrm{C}(17) \quad 125 \cdot 5$ (2) C(48)-C(18)-C(19) 127.9 (3) $\mathrm{C}(20)-\mathrm{C}(19)-\mathrm{C}(18) \quad 128.0$ (3) $\mathrm{N}(24)-\mathrm{C}(19)-\mathrm{C}(18) 109.6$ (2) $\mathrm{N}(24)-\mathrm{C}(19)-\mathrm{C}(20) \quad 122.4$ (2) $\mathrm{C}(19)-\mathrm{C}(20)-\mathrm{C}(1) \quad 128.9$ (3) $\mathrm{O}(25)-\mathrm{C}(20)-\mathrm{C}(1) \quad 115.0(2)$ $O(25)-C(20)-C(19) 116 \cdot 1$ (2) $\mathrm{C}(4)-\mathrm{N}(21)-\mathrm{C}(1) \quad 107 \cdot 3(2)$ $\mathrm{C}(9)-\mathrm{N}(22)-\mathrm{C}(6) \quad 108.0(2)$ C(14)-N(23)-C(11) 107.0 (2) $\mathrm{C}(19)-\mathrm{N}(24)-\mathrm{C}(16) \quad 107.7$ (2) $\mathrm{C}(26)-\mathrm{O}(25)-\mathrm{C}(20) \quad 115.5$ (2) $\mathrm{O}(27)-\mathrm{C}(26)-\mathrm{O}(25) \quad 122.4(3)$ $\mathrm{C}(28)-\mathrm{C}(26)-\mathrm{O}(25) \quad 112.0$ (3) $\mathrm{C}(28)-\mathrm{C}(26)-\mathrm{O}(27) \quad 125.6(3)$ $\mathrm{C}(29)-\mathrm{C}(28)-\mathrm{C}(26) \quad 123.7$ (3) C(33)-C(28)-C(26) 117.0 (3) $\mathrm{C}(33)-\mathrm{C}(28)-\mathrm{C}(29) \quad 119.2$ (3) C(30)-C(29)-C(28) 120.4 (3) C(31)-C(30)-C(29) 120.2 (4) $C(32)-C(31)-C(30) \quad 120.2$ (4) C(33)-C(32)-C(31) 119.6 (4) $\mathrm{C}(32)-\mathrm{C}(33)-\mathrm{C}(28) \quad 120.4$ (4) C(35)-C(34)-C(2) 113.3 (2) $C(37)-C(36)-C(3) \quad 111.9$ (2) C(39)-C(38)-C(7) 114.2 (3) C(41)-C(40)-C(8) 113.7 (3) C(43)-C(42)-C(12) 113.5 (3) $C(45)-C(44)-C(13) \quad 112.7$ (3) C(47)-C(46)-C(17) 112.2 (3) C(49)-C(48)-C(18) 112.5 (3)

and $D$ on the other, falling into two distinct groups (Table 5). Similar differences have been observed in the parent compounds octaethylporphyrin (Lauher \& Ibers, 1973) and in porphyrin itself (Chen \& Tulinsky, 1972) and are considered to be expected for a hybrid of the two major resonance forms of the macrocycle. In BOEP, as in octaethylporphyrin, ethyl substitution on the pyrrole rings has lengthened those bonds adjacent to the site of substitution, compared to porphyrin itself. The highly-delocalized $\pi$-electron system of the porphyrin skeleton is responsible for the observed equivalence in length of the four pairs of bridging $\mathrm{C}-\mathrm{C}$ bonds.

The location, in the non-symmetrical structure of BOEP, of four 'half-hydrogen' atoms attached to the four central $\mathrm{N}$ atoms is an unexpected finding, in the light of the structural data available on a number of other porphyrin-containing structures. The original structure determination of free-base porphyrin (Webb
Table 5. Averaged observed bond distances (in $\AA$ ) for the pyrrole rings in $B O E P$

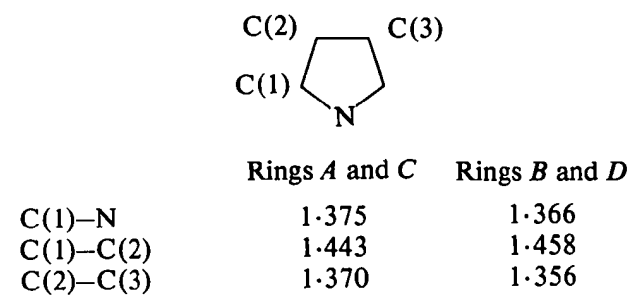

Each pyrrole ring has been assigned twofold symmetry.

Table 6. Characteristics of the 'half-hydrogen' atoms attached to the four central nitrogen atoms

$\begin{array}{ccc} & d(\text { in } \AA) & U\left(\AA^{2} \times 10^{3}\right) \\ \mathrm{H}(21)-\mathrm{N}(21) & 1.00(5) & 49(13) \\ \mathrm{H}(22)-\mathrm{N}(22) & 0.85(5) & 56(15) \\ \mathrm{H}(23)-\mathrm{N}(23) & 1.17(4) & 29(12) \\ \mathrm{H}(24)-\mathrm{N}(24) & 0.77(5) & 40(13)\end{array}$

Observed heights of the peaks assigned to be the four 'halfhydrogen' atoms, from a difference Fourier synthesis, in e $\AA^{-3}$

$\begin{array}{llll}\mathrm{H}(21) & 0.26 & \mathrm{H}(23) & 0.27 \\ \mathrm{H}(22) & 0.24 & \mathrm{H}(24) & 0.23\end{array}$

\& Fleischer, 1965) located what were originally considered to be four half-hydrogens; however a subsequent re-determination using extremely pure base (Chen \& Tulinsky, 1972) located only two 'fullhydrogens' attached to $\mathrm{N}$ atoms in rings $A$ and $C$ (or $B$ and $D$ ). It was considered that as the earlier analysis was complicated by their being $5-10 \%$ of metallo impurity in the porphyrin sample (the metal would reside at the centre of the molecule), the four halfhydrogen assignment was questionable. Two localized full-hydrogens have also been observed in the crystal structures of octaethylporphyrin (Lauher \& Ibers, 1973), mesoporphyrin IX dimethyl ester (Little \& Ibers, 1975), and protoporphyrin IX dimethyl ester (Caughey \& Ibers, 1977). The parameters for the four 'halfhydrogens' in BOEP are detailed in Table 6. The N-H

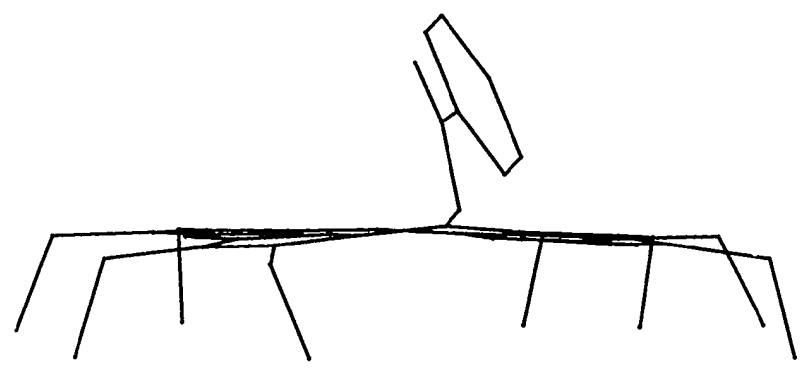

Fig. 2. The molecule, viewed along the four-nitrogen plane. 

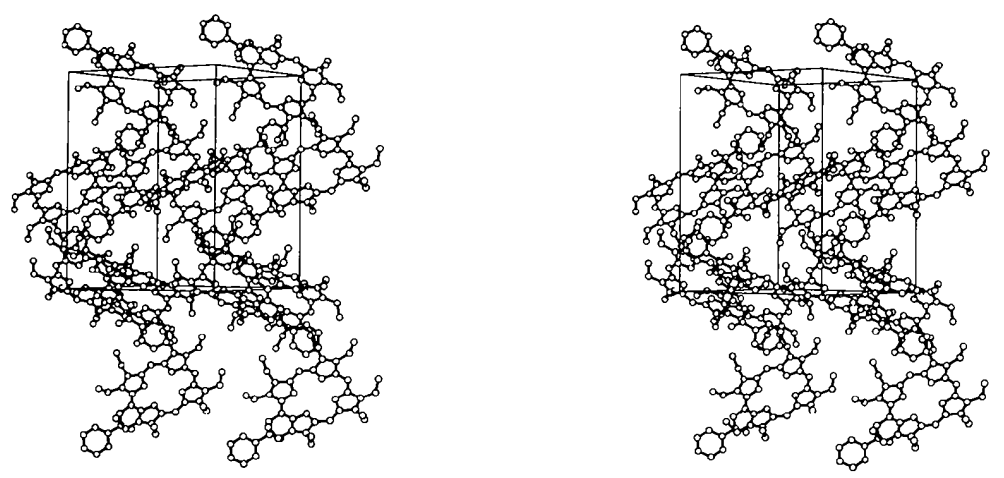

Fig. 3. The packing of BOEP molecules in the unit cell.

Table 7. Deviations $(\AA)$ of atoms from the least-squares planes of various parts of the molecule

Atoms whose deviations are marked with an asterisk have been included in the calculation of the plane.

Plane 1: $C(1) 0.096 ; C(2) 0.085 ; C(3)-0.027 ; C(4)-0.047$; $\mathrm{C}(5)-0.048 ; \mathrm{C}(6)-0.010 ; \mathrm{C}(7) 0.041$; $\mathrm{C}(8) 0.065$; $C(9) 0.053 ; C(10) 0.083 ; C(11) 0.040 ; C(12) 0.017$ $C(13)-0.035 ; C(14)-0.040 ; C(15)-0.083$; $C(16)-0.099 ; C(17)-0.235 ; C(18)-0.192$; $\mathrm{C}(19)-0.012 ; \mathrm{C}(20) 0.155 ; \mathrm{N}(21) 0.000^{*}$; $\mathrm{N}(22) 0.000^{*} ; \mathrm{N}(23) 0.000^{*} ; \mathrm{N}(24) 0.000^{*}$

Plane 2: (Ring $A$ )

$\mathrm{C}(1) 0.002^{*} ; \mathrm{C}(2) 0.006^{*} ; \mathrm{C}(3)-0.011^{*} ; \mathrm{C}(4) 0.012^{*}$; $\mathrm{N}(21)-0.009^{*}$

Plane 3: (Ring $B$ )

$\mathrm{C}(6)-0.002^{*} ; \mathrm{C}(7) 0.005^{*} ; \mathrm{C}(8)-0.006^{*} ; \mathrm{C}(9) 0.004^{*}$; $\mathrm{N}(22)-0.001^{*}$

Plane 4: (Ring $C$ )

$\mathrm{C}(11) 0.001^{*} ; \mathrm{C}(12) 0.000^{*} ; \mathrm{C}(13)-0.002^{*}$; $C(14) 0.002^{*} ; N(23)-0.002^{*}$

Plane 5: (Ring $D$ )

$\mathrm{C}(16) 0.010^{*} ; \mathrm{C}(17)-0.001^{*} ; \mathrm{C}(18)-0.007 *$ $\mathrm{C}(19) 0.014^{*} ; \mathrm{N}(24)-0.015^{*}$

bond lengths show greater variation than might be expected - this may suggest that the four hydrogens are non-equivalent, or that the estimated standard deviations have been underestimated. However, one cannot discount the possibility that the observation of four half-weight hydrogens, instead of two full-weight ones, is a crystallographic artifact. The presence of metallo impurities ( $c f$. porphyrin itself) is considered to be unlikely since (i) the atomic and thermal coordinates refined reasonably satisfactorily and (ii) in contrast to free base porphyrin, the difference Fourier syntheses showed no electron density at the centre of the macrocycle, which would indicate the presence of some metal ion.
In solution, it is well established that $\mathrm{N}-\mathrm{H}$ tautomerism occurs; it has been observed for mesoporphyrin IX dimethyl ester (Little \& Ibers, 1975), and for octaethylporphyrin (Kawano, Ozaki, Kyogoku \& Ogoshi, 1977). In view of the fact that BOEP is not a symmetrical structure, this possible tautomerism finding is unexpected, and on the basis of the crystallographic data cannot be definitively assigned.

The BOEP molecule is significantly ruffled, as shown in Table 7 and Fig. 2, with the overall shape approximating to a shallow saucer [ $c f$. vanadyldeoxophylloerythroetioporphyrin (Pettersen, 1969), and ethyl chlorophyllide $a$ (Chow, Serlin \& Strouse, 1975)]. All four pyrrolic rings are planar - the deviations for rings $A$ and $D$ are barely significant. The four rings are inclined at angles of $4 \cdot 0,2 \cdot 0,2 \cdot 1$ and $6.2^{\circ}$ respectively, to the best plane through the four $\mathrm{N}$ atoms and the aromatic substituent is at $61^{\circ}$ to this plane. Rings $A$ and $D$ are mutually inclined at $9.9^{\circ}$. The ruffling has also induced a marked asymmetry in the central $\mathrm{N}-\mathrm{N}$ distances, compared to non-meso-substituted porphyrins, which tend to possess a square-planar arrangement. Here, $\mathrm{N}(21)-\mathrm{N}(22)$ is $2.984 \AA$, $\mathrm{N}(21)-\mathrm{N}(24)$ is $2.849 \AA, \mathrm{N}(22)-\mathrm{N}(23)$ is $2.849 \AA$, and $\mathrm{N}(23)-\mathrm{N}(24)$ is $2.977 \AA$ (again $c f$. the chlorophyll analogues mentioned above). A rhomboid arrangement has recently been observed in a meso-bis(ethoxycarbonylvinyl)octaethylporphyrin (Sheldrick, 1977). The packing of BOEP molecules in the crystal lattice (Fig. 3) involves no unduly close contacts.

We are grateful to Professor R. Bonnett for the provision of crystals and for useful discussions, to Professor D. Rogers, for the use of his diffractometer, and to the referee for his comments.

\section{References}

Allen, F. H., Rogers, D. \& Troughton, P. G. H. (1971). Acta Cryst. B27, 1325-1337.

BonNETT, R. (1972). Ann. NY Acad. Sci. 206, 723-733. 
Caughey, W. S. \& Ibers, J. A. (1977). J. Am. Chem. Soc. 99, 6639-6645.

Chen, B. M. L. \& Tulinsky, A. (1972). J. Am. Chem. Soc. 94, 4144-4151.

Chow, H.-C., Serlin, R. \& Strouse, C. E. (1975). J. Am. Chem. Soc. 97, 7230-7237.

Hursthouse, M. B. \& Neidle, S. (1972). J. Chem. Soc. Chem. Commun. p. 449.

KaWano, K., Ozaki, Y., KYogoku, Y. \& Ogoshi, H. (1977). J. Chem. Soc. Chem. Commun. pp. 226-227.
Lauher, J. W. \& Ibers, J. A. (1973). J. Am. Chem. Soc. 95, 5148-5152.

Little, R. G. \& I Bers, J. A. (1975). J. Am. Chem. Soc. 97, 5363-5369.

Long, R. E. (1965). PhD Thesis, Univ. of California, Los Angeles.

Pettersen, R. C. (1969). Acta Cryst. B25, 2527-2539.

SHELDRICK, W. S. (1977). Acta Cryst. B33, 3967-3970.

Webi, L. E. \& Fleischer, E. B. (1965). J. Chem. Phys. 43, $3100-3111$.

Acta Cryst. (1978). B34, 2514-2517

\title{
Crystal Structure of Anhydro-2-methyl-4-o-nitroanilino-1,2,3-benzotriazinium Hydroxide
}

\author{
By Carl H. Schwalbe, * Malcolm F. G. Stevens and Philip R. Lowe \\ Department of Pharmacy, The University of Aston in Birmingham, Gosta Green, Birmingham B4 7ET, England
}

(Received 3 January 1978; accepted 7 March 1978)

$\mathrm{C}_{14} \mathrm{H}_{11} \mathrm{~N}_{5} \mathrm{O}_{2}$ crystallizes in the monoclinic space group $P 2_{1} / c$ with $a=8.233(3), b=7.764(2), c=$ $20.799(5) \AA, \beta=93.11(2)^{\circ}, Z=4, D_{c}=1.41, D_{m}=1.38 \mathrm{~g} \mathrm{~cm}^{-3}$. From 1001 observed reflexions measured on a four-circle diffractometer or on Weissenberg films the structure was solved by MULTAN and refined by full-matrix least-squares procedures to $R=0.105, R_{w}=0.080$. The benzotriazine ring and exocyclic nitrogen together form a planar delocalized system with the exocyclic $\mathrm{C}-\mathrm{N}$ distance only $1.29 \AA$. The bond from this nitrogen to a phenyl carbon is $1.41 \AA$ long and twisted so that the benzotriazine and phenyl planes intersect at $72.5^{\circ}$. The imino character of this nitrogen explains its relatively low basicity.

\section{Introduction}

The stable red title compound (II) was prepared (55\%) by reaction of 4-o-nitroanilino-1,2,3-benzotriazine (I) with methyl iodide in ethanolic sodium ethoxide solution (Stevens \& Stevens, 1970). Compound (II)

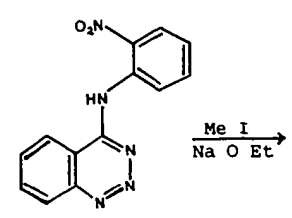

(I)

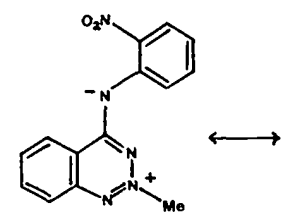

(II $a)$

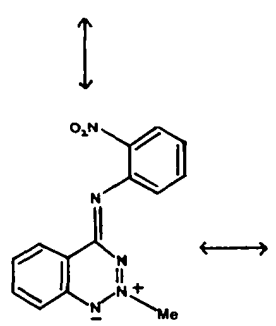

(IIc)

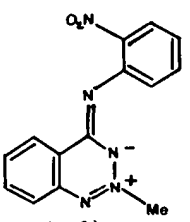

(IIb)

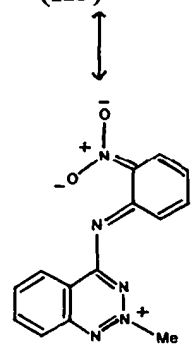

(IId)
* To whom correspondence should be addressed. belongs to a small class of benzotriazinium betaines which can be prepared directly by alkylation (Stevens \& Stevens, 1970; Wagner \& Gentzsch, 1968) or arylation (McKillop \& Kobylecki, 1974) of appropriately substituted 1,2,3-benzotriazines, or indirectly by mild oxidation of $o$-nitrobenzaldehyde arylhydrazones (Kerber, 1972).

Methylation of benzotriazine (I) could involve $\mathrm{N}(1)$, $\mathrm{N}(2), \mathrm{N}(3)$, or the exocyclic $\mathrm{N}$ atom, and the evidence supporting structure (II) for the red product was not entirely convincing, being based on spectroscopic and degradative studies (Stevens \& Stevens, 1970; Johnstone, Payling, Preston, Stevens \& Stevens, 1970). The latter experiments were difficult to interpret because of the possibility for methyl-group rearrangement during degradation. We therefore wanted to verify structure (II) by X-ray diffraction methods, particularly because the related 1,2,3-benzotriazinium iodides (III) exhibit interesting pharmacological properties (Cull \& Scott, 1973; French \& Scott, 1977). These iodides, on basification, afford intensely coloured, unstable betaines (IV) which are devoid of pharmacological activity. Several contributing structures (II $a$ d) can be written for the nitrobenzotriazine with positive formal charge located at $\mathrm{N}(2)$ but negative 